\title{
MENGGAGAS FIKIH ANTI KORUPSI
}

\author{
Syamsuri \\ Dosen Tetap Fakultas Syariah IAIN Sunan Ampel Surabaya
}

\begin{abstract}
Abstrak: Sepanjang perjalanan sejarah bangsa Indonesia, korupsi bagi sebagian orang telah menjelma menjadi jalan pintas untuk meraup harta yang bukan haknya sebanyak-banyaknya. Tetapi, sejarah bangsa ini juga mencatat bahwa semangat melawan korupsi tidak pernah mati. Korupsi selalu diposisikan sebagai public enemy dan menjadi kejahatan yang paling menakutkan mengalahkan kejahatan-kejahatan lainnya. Dilihat dari dampak yang diakibatkan, kejahatan yang bernama korupsi mempunyai dampak yang sistemis dibanding kejahatan lainnya. Islam diyakini mempunyai solusi mengatasi penyakit social ini. Islam menyebut korupsi sebagai sebuah jarimah, kejahatan yang pelakunya harus dikenai hukuman di dunia, di samping balasan kelak di akhirat. Kejahatan korupsi dikategorikan sebagai al-khiyanah yang berarti penyelewengan terhadap kepercayaan. Penyelewengan yang tentu saja immoral dan mencederai kemanusiaan.
\end{abstract}

Kata Kunci: Fikih, korupsi, public enemy, jarimah, penyakit sosial.

\section{Pendahuluan}

Sebagai agama samawi terakhir, ajaran Islam diyakini mencakup dan menyentuh seluruh aspek kehidupan manusia. Ia hadir dengan misi suci, membangun peradaban manusia yang benar, damai dan berkeadilan. Keberpihakan Islam terhadap kedamaian, keadilan dan kebenaran ini tidak perlu diragukan.

Dalam usaha membumikan ajaran-ajaran Islam, khususnya di bidang hukum, para mujtahid telah melakukan telaah yang berkesinambungan dari masa ke masa terhadap nass syarak guna menjawab dinamika peradaban manusia. Telaah mereka terhadap nass syarak inilah yang disebut dengan fikih, yang selanjutnya terbukukan dalam literatur-literatur keislaman yang dikenal sebagai kitab fikih. Dalam kenyataannya, cakupan aspek hukum Islam yang menjadi obyek kajian para mujtahid sangat luas, 
meliputi hubungan vertikal dan horisontal. Untuk itu mereka membagi domain pembahasan fikih kepada dua bagian: bagian ibadah yang cenderung tetap (thabit) dan rigid, dan bagian muamalah yang cenderung dinamis (mutaghayyir) dan elastis. Dengan dua bagian ini, hukum Islam terbukti menjadi salih li kull al-zaman wa al-makan ( selaras dengan perkembangan zaman).

Saat ini korupsi sebagai sebuah praktek kejahatan telah menjadi istilah yang paling populer dan menakutkan. Secara bahasa korupsi berasal dari bahasa Inggris corruption yang berarti jahat atau busuk, moral yang rusak, atau bertindak tidak jujur untuk kepentingan pribadi. ${ }^{1}$ Dalam Kamus Besar Bahasa Indonesia korupsi diartikan sebagai penyelewengan atau penggelapan (uang negara atau perusahaan, dan sebagainya) untuk keuntungan pribadi atau golongan. ${ }^{2}$

Dilihat dari pengertiannya, sekilas korupsi tidak tampak lebih jahat dari kejahatan jenis lainnya. Korupsi, pencurian, perampokan dan pencopetan adalah sama-sama kejahatan terhadap harta yang bukan miliknya. Kejahatan apapun jenisnya adalah perbuatan immoril yang karenanya pasti sama-sama anti sosial. ${ }^{3}$ Namun demikian, jika dilihat dari dampak yang diakibatkan oleh kejahatan tersebut, maka korupsi akan tampak jauh lebih berbahaya karena mempunyai dampak yang sistemis dibanding kejahatan lainnya.

\section{Kejahatan Korupsi}

Istilah korupsi berasal dari bahasa latin corruptus yang bermakna merusak atau kebobrokan, kemudian dialih bahasakan ke dalam bahasa Inggris menjadi corruption dan ke dalam bahasa

'Reader's Digest, Word Power Dictionary (Sydney: The Reader's Digest Association Limited, 200I), h. 21 I.

2Departemen Pendidikan dan Kebudayaan, Kamus Besar Bahasa Indonesia (Jakarta: PN. Balai Pustaka, 1976), h. 524.

${ }^{3}$ W. A. Bonger, Pengantar Tentang Kriminologi (lakarta: Ghalia Indonesia, 1982), h. 22.

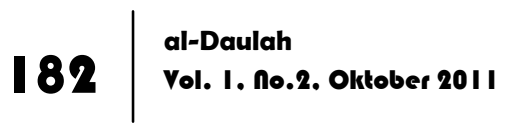


Belanda menjadi corruptie. Dalam Pengertian yang luas korupsi dapat dimaknai sebagai berikut: ${ }^{4}$

1. Penyelewengan atau penggelapan (uang Negara atau perusahaan dan sebagainya) untuk kepentingan pribadi dan orang lain.

2. Korupsi dapat berarti busuk, rusak, suka memakai barang atau uang yang dipercayakan kepadanya, dapat disogok (melalui kekuasaannya untuk kepentingan pribadi).

Menurut Subekti dan Tjitrosoedibio dalam Kamus Hukum, bahwa yang dimaksud korupsi adalah "perbuatan curang dan tindak pidana yang merugikan Negara". Senada dengan pengertian tersebut Andi Hamzah menyatakan bahwa dalam kehidupan sehari-hari korupsi diartikan sebagai "tindakan seorang pegawai negeri yang menyalahgunakan kekuasaan resmi dengan maksud memperoleh penghasilan tambahan untuk diri sendiri dari khalayak ramai". ${ }^{5}$

Selain pengertian korupsi yang telah disebutkan di atas, JW Schoorl mendefinisikan korupsi dengan "penggunaan kekuasaan negara untuk memperoleh penghasilan, keuntungan atau prestise perorangan atau untuk memberi keuntungan bagi sekelompok orang atau suatu kelas sosial dengan cara yang bertentangan dengan undang-undang atau dengan norma akhlak yang tinggi." 6

Menurut Hermien Hadiati Koeswadji, dalam hukum positif korupsi disimpulkan sebagai: ${ }^{7}$

1. Melakukan perbuatan untuk memperkaya diri atau orang lain, atau suatu badan, perbuatan memperkaya itu diartikan berbuat apa saja seperti mengambil, memindah bukukan, menandatangani kontrak dan sebagainya.

${ }^{4}$ Evi Hartanti, Tindak Pidana Korupsi (Jakarta: Sinar Grafika Offset, 2005), h. 9.

${ }^{5}$ Andi Hamzah, Korupsi di Indonesia: Masalah dan Pemecahannya (Jakarta: Gramedia Pustaka Umum, 1991), h. 7.

ஏ. W. Schoorl, Modernisasi: Pengantar Sosiologi Pembangunan Negara Sedang Berkembang (Jakarta: Gramedia, 1980), h. 175.

${ }^{7}$ Hermien Hadiati Koeswadji, Korupsi di Indonesia: Dari Delik Jabatan ke Tindak Pidana Korupsi (Bandung: PT. Citra Aditya Bakti, 1994), h. 62.

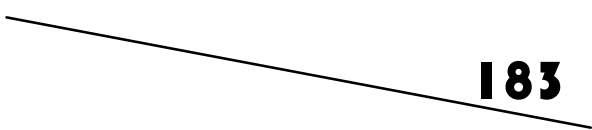


2. Perbuatan yang melawan hukum, maksud hukum disini secara formil dan materiil, dan harus dibuktikan karena dicantumkan secara tegas dalam rumusan delik.

3. Perbuatan yang secara langsung, maupun tidak langsung merugikan negara dari atu perekonomian negara.

Sedangkan pengertian korupsi sebagai sebuah kejahatan dapat dilihat secara lengkap pada pasal 2 Undang-Undang No. 31 Tahun 1999 yang diperkuat dan tidak diadakan perubahan oleh Undang-Undang No. 20 Tahun 2001. Menurut pasal ini, pengertian korupsi sebagaimana dijabarkan secara tuntas dalam ketiga ayatnya adalah sebagai berikut :

(1) Setiap orang yang secara melawan hukum melakukan perbuatan memperkaya diri sendiri atau orang lain atau suatu korporasi yang dapat merugikan keuangan negara atau perekonomian negara.

(2) Setiap orang yang secara melawan hukum melakukan perbuatan memperkaya diri sendiri atau orang lain atau suatu korporasi yang dapat merugikan keuangan negara atau perekonomian negara yang sementara dana itu diperuntukkan bagi penangulangan keadaan bahaya,bencana alam nasional, penanggulangan akibat kerusuhan sosial yang meluas, penanggulangan krisis ekonomi moneter dan penanggulangan tindak pidana korupsi.

(3) Setiap orang yang dengan tujuan menguntungkan diri sendiri atau orang lain atau korporasi, menyalahgunakan kewenangan, kesempatan, atau sarana yang ada padanya karena jabatan atau kedudukan yang dapat merugikan keuangan negara atau perekonomean negara.

Dari beragam definisi yang dikemukakan para pakar dan pengertian yang ditegaskan oleh UU anti korupsi, Alatas menyimpulkan ciri-ciri tindak kejahatan yang dapat dikatagorikan sebagai tindak pidana korupsi sebagai berikut: ${ }^{8}$

${ }^{8}$ Alatas, The Sociology of Corruption (Singapore: Times International, 1980), h. 25.

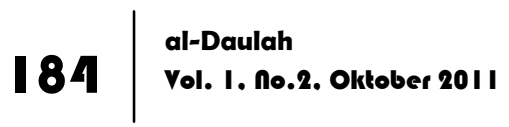


1. Suatu pengkhianatan terhadap kepercayaan.

2. Penipuan terhadap badan pemerintah, lembaga swasta/ masyarakat umum.

3. Secara sengaja melalaikan kepentingan umum untuk kepentingan pribadi.

4. Dilakukan dengan rahasia, kecuali dalam keadaan di mana orang-orang yang berkuasa dan bawahannya sudah tahu sama tahu.

5. Melibatkan lebih dari satu orang/pihak.

6. Terdapat kewajiban dan keuntungan bersama, baik dalam bentuk uang atau lainnya.

7. Terpusatnya usaha untuk menutupi perbuatan korup dalam bentuk pengesahan hukum.

8. Menununjukkan fungsi ganda yang kontradiktif pada para pelaku korupsi.

Dari ciri-ciri korupsi sebagaimana disampaikan Alatas tersebut, dapat diambil kesimpulan bahwa korupsi itu perbuatan khianat yang memanfaatkan jabatan atau kedudukan yang dipercayakan kepadanya (amanah) untuk mendapatkan keuntungan pribadi, orang lain atau kelompoknya dan berakibat merugikan orang atau pihak lain.

Baharuddin Lopa membagi korupsi berdasarkan motif yang melatarbelakangi tindak pidana tersebut kepada dua katagori: ${ }^{9}$

1. Korupsi yang bermotif terselubung, yaitu korupsi yang secara sepintas terkesan bermotif politik, tetapi motif sesungguhnya adalah uang semata. Seperti uang suap yang diterima seorang pejabat sebagai jaminan agar pemberi suap memperoleh jabatan tertentu.

2. Korupsi yang bermotif ganda, yaitu korupsi yang secara sepintas hanya bermotif untuk mendapatkan uang, tetapi sesungguhnya mempunyai motif ganda; uang dan kepentingan politik. Seperti penyogokan terhadap pejabat

${ }^{9}$ Nilawati, "Penyakit yang Menggiurkan Itu Bernama Korupsi", dalam Suyitno, et.al., Korupsi: Hukum \& Moralitas Agama (Yogyakarta: Gama Media, 2006), h. 57.

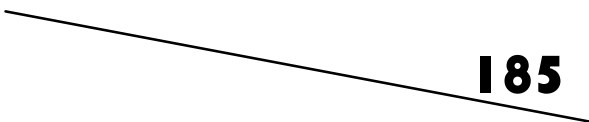


untuk melakukan penyalahgunaan wewenang dengan memberikan fasilitas tertentu kepada pihak-pihak tertentu.

Selain itu, beberapa faktor penyebab terjadinya korupsi juga dikemukakan oleh Syed Husein Alatas, antara lain: ${ }^{10}$

1. Ketiadaan atau kelemahan kepemimpinan dalam posisi-posisi strategis yang mampu memberikan contoh dan mempengaruhi tingkah laku yang menjinakkan korupsi.

2. Kelemahan pengajaran-pengajaran agama dan etika.

3. Kurangnya pendidikan.

4. Adanya kemiskinan.

5. Tiadanya tindak atau sanksi hukuman yang keras

6. Kurangnya lingkungan yang kondusif untuk prilaku anti korupsi.

7. Keadaan atau kondisi masyarakat.

Walaupun korupsi menjadi kejahatan yang luar biasa, bukan berarti korupsi tidak dapat diberantas atau dihilangkan. Mental korupsi yang kemudian menjadi budaya itu dapat diberantas dengan terpenuhinya beberapa faktor solutif berikut ini, yaitu:

1. Keterikatan positif pada pemerintahan dan keterlibatan spiritual serta tugas kemajuan nasional dalam kancah publik maupun birokrasi;

2. Administrasi yang efesien serta penyesuaian struktural yang layak dari mesin dan aturan pemerintah sehingga menghindari penciptaan sumber-sumber korupsi;

3. Kondisi sejarah dan sosiologis yang menguntungkan;

4. Berfungsinya sistem yang antikorupsi; dan

5. Kepemimpinan kelompok yang berpengaruh dengan standar moral dan intelektual yang tinggi. ${ }^{11}$

\section{Upaya Bangsa Indonesia Memerangi Korupsi}

Kesadaran bahwa tindak pidana korupsi adalah kejahatan besar yang senantiasa menjadi common enemy (musuh bersama)

\footnotetext{
${ }^{10}$ Syeid Husein Alatas, Sosiologi Korupsi (Jakarta: LP3ES, 1982), h. 48.

"Nilawati, Penyakit yang Menggiurkan Itu Bernama Korupsi, h. 63.
} 
dan semangat untuk memberantasnya, sebenarnya telah lama tertanam dalam benak rakyat Indonesia. Hal ini terbukti dari catatan panjang sejarah perundang-undangan anti korupsi yang pernah kita miliki dan diberlakukan di negeri ini.

Pembicaraan tentang korupsi dalam undang-undang dimulai dari Kitab Undang-Undang Hukum Pidana atau disingkat KUHP (Wetboek van Strafrecht) yang diberlakukan jauh sebelum Indonesia merdeka. Dalam KUHP yang diundangkan dalam Stbl 1915 Nomor 752, berdasarkan KB 15 Oktober 1915 dan kemudian diberlakukan sejak 1 Januari 1918 ini, delik-delik korupsi di masukkan sebagai sebuah kejahatan biasa, bukan pelanggaran. Delik korupsi yang merupakan delik jabatan dimuat dalam BAB XXVIII buku II KUHP. Sedangkan delik korupsi yang ada kaitannya dengan delik jabatan seperti pasal 209 dan 210 dimuat dalam buku yang sama, yaitu buku II KUHP (tentang kejahatan) tetapi berada di dalam bab yang lain. ${ }^{12}$ Beberapa delik korupsi yang tercantum dalam pasal-pasal KUHP adalah: Pasal 209, 210, 220, 231, 387, 388, 415, 416, 417, 418, 419, 420, 421, 422, 423, 425, 429 , dan 430 .

Selanjutnya pada tahun 1957, peraturan pemberantasan korupsi yang pertama setelah kemerdekaan lahir, yaitu Peraturan Penguasa Militer tanggal 9 April 1957 Nomor Prt/PM/06/1957, tanggal 27 Mei 1957 Nomor Prt/PM/03/1957, dan tanggal 1 Juli 1957 Nomor Prt/ PM/011/1957.

Lahirnya peraturan tersebut menunjukkan bahwa delik korupsi saat itu mulai tumbuh subur dan tidak dapat diberantas begitu saja dengan pasal-pasal yang terdapat dalam KUHP. Peraturan ini juga menjadi bukti bahwa usaha untuk melawan korupsi sebagai sebuah kejahatan tidak pernah berhenti di negeri ini. Hal ini ditunjukkan dengan bunyi konsideran dari peraturan yang pertama tersebut menyatakan:

${ }^{12}$ Andi Hamzah, Korupsi di Indonesia, h. 38.

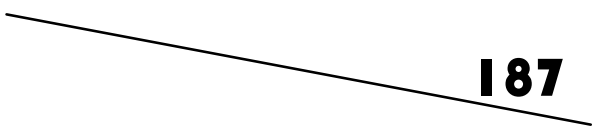


"Bahwa berhubung tidak adanya kelancaran dalam usahausaha memberantas perbuatan-perbuatan yang merugikan keuangan dan pereonomian Negara,yang oleh khalayak ramai dinamakan korupsi,perlu segera menetapkan suatu tatacara kerja untuk dapat menerobos kemacetan dalam usaha-usaha dalam memberantas korupsi..."..$^{13}$

Ketika pasal 60 Undang-undang Keadaan Bahaya No. 74 Tahun 1957 tidak diberlakukan lagi, ketiga Peraturan Penguasa Militer tersebut diganti dengan Peraturan Pemberantasan Korupsi Prn Penguasa Perang Pusat Nomor Prt/Peperpu/013/1958 yang ditetapkan dan diumumkan pada tanggal 16 April 1958 dan disiarkan di BN Nomor 40/1958 ${ }^{14}$.

Oleh karena Peraturan Penguasa Perang Pusat tentang Pemberantasan Korupsi tersebut bersifat darurat dan sementara yang berlandaskan Undang-undang Keadaan Bahaya, maka kemudian diganti dan disahkan menjadi Undang-undang. Selanjutnya semua perumusan delik yang ada dalam Peraturan Penguasa Perang Pusat diambil alih sepenuhnya oleh UndangUndang Nomor 24 (Prp) Tahun 1960 dengan sedikit perubahan kata-kata seperti perbuatan menjadi tindakan (Pasal 1 ayat (1) sub a dan b) dan penambahan pasal 415,416,417,423,425, dan 435 KUHP pada sub c. ${ }^{15}$

Ketika pada tahun 1966 Orde baru lahir, kejahatan yang bernama korupsi tidak juga surut. Malah sebaliknya dari tahun ke tahun semakin merajalela. Akibatnya tuntutan dari berbagai kalangan untuk segera melakukan pemberantasan korupsi semakin nyaring terdengar. Tuntutan tersebut akhirnya direspon presiden dengan mengeluarkan dua keputusan Presiden pada tanggal 31 Januari 1970. Keputusan Presiden tersebut adalah Kepres No. 12 Tahun 1970 tentang Pembentukan Komisi 4 dan

\footnotetext{
${ }^{13}$ Ibid., h. 4I.

${ }^{14}$ /bid., h. 42.

$15 /$ bid., h. 62.
} 
Kepres No. 13 tahun 1970 tentang pengangkatan Dr. Mohammad Hatta sebagai penasehat presiden.

Pada tanggal 10-12 Agustus 1970, Dewan Mahasiswa Universitas Indonesia mengadakan diskusi panel tentang hukum dan korupsi yang menghadirkan tokoh-tokoh terkemuka saat itu. Hasil panel tersebut selanjutnya ditanggapi Pemerintah dengan membuat rencana Undang-undang anti korupsi yang baru dan dilimpahkan kepada DPR-GR.

Dalam pembahasan Rancangan Undang-undang anti korupsi tersebut, terdapat perbedaan pendapat antara Pemerintah dan DPR-GR. Beberapa perbedaan tersebut antara lain sebagai berikut:

1. Pembahasan pasal 17. Anggota DPR-GR menghendaki diberlakukannya asas pembuktian terbalik (omkering van bewijslast), tetapi pihak Pemerintah, dalam hal ini Menteri Kehakiman Oemar Seno Adji, menolak pembuktian terbalik karena melanggar prinsip nonselfin crimination sebagai hak seseorang dalam suatu perkara pidana.

2. Pembahasan pasal 36 tentang pemberlakuan surut Undangundang Pemberantasan Tindak Pidana Korupsi. Beberapa anggota DPR-GR menghendaki agar undang-undang tersebut diberlakukan surut, sementara Pemerintah berpendapat tidak dapat berlaku surut.

Pada akhirnya, Rancangan Undang-undang tersebut disetujui dan disahkan menjadi Undang-undang No. 3 Tahun 1971 Tentang Pemberantasan Tindak Pidana Korupsi pada tanggal 29 Maret 1971 dan diundangkan pada tanggal yang sama, termuat dalam Lembaran Negara Tahun 1971 Nomor 19.16

Pada saat Habibi menggantikan Soeharto sebagai presiden tahun 1998, hal pertama yang dicanangkan adalah penggantian Undang-undang No. 3 Tahun 1971 tentang Pemberantasan Tindak Pidana Korupsi. Maka pada bulan Juli 1999 Rancangan Undangundang yang tersebut dibahas di DPR. Dalam pembahasan

${ }^{16} /$ bid., h. 70-73.

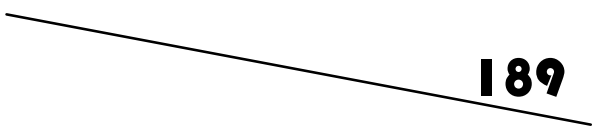


tersebut disepakati adanya penambahan pidana mati untuk delik yang tercantum dalam pasal 2. Yang tidak kalah menarik adalah adanya tambahan tentang akan dibentuknya Komisi Pemberantasan Korupsi (KPK). Baru pada tanggal 16 Agustus 1999 diundangkan Undang-undang No. 31 Tahun 1999 tentang Pemberantasan Tindak Pidana Korupsi menggantikan UndangUndang No. 3 Tahun $1971,{ }^{17}$ yang tertulis dalam Lembaran Negara Republik Indonesia No. 140. Tambahan Lembar Negara Rebublik Indonesia Tahun 1999 No. 3874.

Sebelumnya, pada tahun yang sama telah lahir UndangUndang RI Nomor 28 Tahun 1999 tentang Penyelenggara Negara yang Bersih dan Bebas dari Korupsi, Kolusi dan Nepotisme yang disahkan dan diundangkan pada tanggal 19 Mei 1999 dan tertulis dalam Lembaran Negara Republik Indonesia Tahun 1999 nomor 75.18

Pada tahun 2001, lahir Undang-Undang No. 20 Tahun 2001 tentang Perubahan atas Undang-Undang No. 31 Tahun 1999 tentang Pemberantasan Tindak pidana Korupsi. Undang-Undang ini lahir dengan pertimbangan, sebagaimana yang tercantum pada bagian awal Undang-Undang tersebut, bahwa tindak pidana korupsi yang terjadi secara meluas, tidak hanya merugikan keuangan negara, tetapi juga telah merupakan pelanggaran terhadap hak-hak sosial dan ekonomi masyarakat secara luas, sehingga tindak pidana korupsi perlu digolongkan sebagai kejahatan luar biasa (extra ordinary crime) yang pemberantasannya harus dilakukan secara luar biasa pula; dan bahwa untuk lebih menjamin kepastian hukum, menghindari keragaman penafsiran hukum dan memberikan perlindungan terhadap hak-hak sosial dan ekonomi masyarakat, serta perlakuan secara adil dalam memberantas tindak pidana korupsi, perlu diadakan perubahan atas Undang-undang Nomor 31 Tahun 1999 tentang Pemberantasan Tindak Pidana Korupsi.

${ }^{17}$ lbid., h. 73-74.

${ }^{18}$ Anonim, "Modules", dalam http://Www.kpk.go.id, dikases pada 20 Pebruari 2010. 
Adapun perubahan yang terdapat dalam Undang-Undang ini adalah penjelasan Pasal 2 ayat (2), ketentuan Pasal 5, Pasal 6, Pasal 7, Pasal 8, Pasal 9, Pasal 10, Pasal 11, dan Pasal 12, rumusannya diubah dengan tidak mengacu pasal-pasal dalam KUHP tetapi langsung menyebutkan unsur-unsur yang terdapat dalam masingmasing pasal KUHP yang diacu. Kemudian di antara Pasal 12 dan Pasal 13 disisipkan tiga pasal baru yakni Pasal 12 A, Pasal 12 B, dan Pasal 12 C, yang berbunyi sebagai berikut:

\section{Pasal 12 A:}

(1) Ketentuan mengenai pidana penjara dan pidana denda sebagaimana dimaksud dalam Pasal 5, Pasal 6, Pasal 7, Pasal 8, Pasal 9, Pasal 10, Pasal 11 dan Pasal 12 tidak berlaku bagi tindak pidana korupsi yang nilainya kurang dari Rp 5.000.000,00 (lima juta rupiah).

(2) Bagi pelaku tindak pidana korupsi yang nilainya kurang dari Rp 5.000.000,00 (lima juta rupiah) sebagaimana dimaksud dalam ayat (1) dipidana dengan pidana penjara paling lama 3 (tiga) tahun dan pidana denda paling banyak Rp 50.000.000,00 (lima puluh juta rupiah).

\section{Pasal 12 B:}

(1) Setiap gratifikasi kepada pegawai negeri atau penyelenggara negara dianggap pemberian suap, apabila berhubungan dengan jabatannya dan yang berlawanan dengan kewajiban atau tugasnya, dengan ketentuan sebagai berikut:

a. yang nilainya $\mathrm{Rp} 10.000 .000,00$ (sepuluh juta rupiah) atau lebih, pembuktian bahwa gratifikasi tersebut bukan merupakan suap dilakukan oleh penerima gratifikasi;

b. yang nilainya kurang dari Rp 10.000.000,00 (sepuluh juta rupiah), pembuktian bahwa gratifikasi tersebut suap dilakukan oleh penuntut umum.

(2) Pidana bagi pegawai negeri atau penyelenggara negara sebagaimana dimaksud dalam ayat (1) adalah pidana penjara seumur hidup atau pidana penjara paling singkat 4 (empat) tahun dan paling lama 20 (dua puluh) tahun, dan pidana

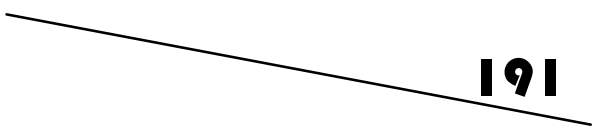


denda paling sedikit $\operatorname{Rp} 200.000 .000,00$ (dua ratus juta rupiah) dan paling banyak Rp 1.000.000.000,00 (satu miliar rupiah).

\section{Pasal 12 C:}

(1) Ketentuan sebagaimana dimaksud dalam Pasal 12 B ayat (1) tidak berlaku, jika penerima melaporkan gratifikasi yang diterimanya kepada Komisi Pemberantasan Tindak Pidana Korupsi.

(2) Penyampaian laporan sebagaimana dimaksud dalam ayat (1) wajib dilakukan oleh penerima gratifikasi paling lambat 30 (tiga puluh) hari kerja terhitung sejak tanggal gratifikasi tersebut diterima.

(3) Komisi Pemberantasan Tindak Pidana Korupsi dalam waktu paling lambat 30 (tiga puluh) hari kerja sejak tanggal menerima laporan wajib menetapkan gratifikasi dapat menjadi milik penerima atau milik negara.

(4) Ketentuan mengenai tata cara penyampaian laporan sebagaimana dimaksud dalam ayat (2) dan penentuan status gratifikasi sebagaimana dimaksud dalam ayat (3) diatur dalam Undang-undang tentang Komisi Pemberantasan Tindak Pidana Korupsi.

Demikian juga di antara Pasal 26 dan Pasal 27 disisipkan satu pasal baru menjadi Pasal 26 A yang berbunyi sebagai berikut:

\section{Pasal 26 A:}

Alat bukti yang sah dalam bentuk petunjuk sebagaimana dimaksud dalam Pasal 188 ayat (2) Undang-undang Nomor 8 Tahun 1981 tentang Hukum Acara Pidana khusus untuk tindak pidana korupsi juga dapat diperoleh dari:

a. alat bukti lain yang berupa informasi yang diucapkan, dikirim, diterima, atau disimpan secara elektronik dengan alat optik atau yang serupa dengan itu; dan

b. dokumen, yakni setiap rekaman data atau informasi yang dapat dilihat, dibaca, dan atau didengar yang dapat dikeluarkan dengan atau tanpa bantuan suatu sarana, baik 
yang tertuang di atas kertas, benda fisik apapun selain kertas, maupun yang terekam secara elektronik, yang berupa tulisan, suara, gambar, peta, rancangan, foto, huruf, tanda, angka, atau perforasi yang memiliki makna.

Selain itu terdapat penambahan pasal, yaitu pasal 37 yang dipecah menjadi dua pasal sehingga menjadi Pasal 37 dan Pasal 37 A, yaitu:

\section{Pasal 37:}

(3) Terdakwa mempunyai hak untuk membuktikan bahwa ia tidak melakukan tindak pidana korupsi.

(4) Dalam hal terdakwa dapat membuktikan bahwa ia tidak melakukan tindak pidana korupsi, maka pembuktian tersebut dipergunakan oleh pengadilan sebagai dasar untuk menyatakan bahwa dakwaan tidak terbukti."

Pasal 37 A dengan substansi yang berasal dari ayat (3), ayat (4), dan ayat (5) dengan penyempurnaan kata "dapat" pada ayat (4) dihapus dan penunjukan ayat (1) dan ayat (2) pada ayat (5) dihapus, serta ayat (3), ayat (4), dan ayat (5) masing-masing berubah menjadi ayat (1), ayat (2), dan ayat (3), sehingga bunyi keseluruhan Pasal 37 A adalah sebagai berikut:

\section{Pasal 37 A:}

(1) Terdakwa wajib memberikan keterangan tentang seluruh harta bendanya dan harta benda istri atau suami, anak, dan harta benda setiap orang atau korporasi yang diduga mempunyai hubungan dengan perkara yang didakwakan.

(2) Dalam hal terdakwa tidak dapat membuktikan tentang kekayaan yang tidak seimbang dengan penghasilannya atau sumber penambahan kekayaannya, maka keterangan sebagaimana dimaksud dalam ayat (1) digunakan untuk memperkuat alat bukti yang sudah ada bahwa terdakwa telah melakukan tindak pidana korupsi.

(3) Ketentuan sebagaimana dimaksud dalam ayat (1) dan ayat (2) merupakan tindak pidana atau perkara pokok sebagaimana dimaksud dalam Pasal 2, Pasal 3, Pasal 4, Pasal 13, Pasal 14,

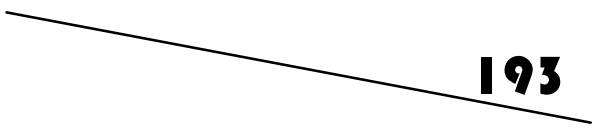


Pasal 15, dan Pasal 16 Undang-undang Nomor 31 Tahun 1999 tentang Pemberantasan Tindak Pidana Korupsi dan Pasal 5 sampai dengan Pasal 12 Undang-undang ini, sehingga penuntut umum tetap berkewajiban untuk membuktikan dakwaannya.

Selain itu terdapat tiga pasal baru juga ditambahkan di antara Pasal 38 dan Pasal 39,yakni Pasal 38 A, Pasal 38 B, dan Pasal 38 C yaitu:

\section{Pasal 38 A:}

Pembuktian sebagaimana dimaksud dalam Pasal 12 B ayat (1) dilakukan pada saat pemeriksaan di sidang pengadilan.

\section{Pasal 38 B:}

(1) Setiap orang yang didakwa melakukan salah satu tindak pidana korupsi sebagaimana dimaksud dalam Pasal 2, Pasal 3, Pasal 4, Pasal 13, Pasal 14, Pasal 15, dan Pasal 16 Undangundang Nomor 31 Tahun 1999 tentang Pemberantasan Tindak Pidana Korupsi dan Pasal 5 sampai dengan Pasal 12 Undangundang ini, wajib membuktikan sebaliknya terhadap harta benda miliknya yang belum didakwakan, tetapi juga diduga berasal dari tindak pidana korupsi.

(2) Dalam hal terdakwa tidak dapat membuktikan bahwa harta benda sebagaimana dimaksud dalam ayat (1) diperoleh bukan karena tindak pidana korupsi, harta benda tersebut dianggap diperoleh juga dari tindak pidana korupsi dan hakim berwenang memutuskan seluruh atau sebagian harta benda tersebut dirampas untuk negara.

(3) Tuntutan perampasan harta benda sebagaimana dimaksud dalam ayat (2) diajukan oleh penuntut umum pada saat membacakan tuntutannya pada perkara pokok.

(4) Pembuktian bahwa harta benda sebagaimana dimaksud dalam ayat (1) bukan berasal dari tindak pidana korupsi diajukan oleh terdakwa pada saat membacakan pembelaannya dalam perkara pokok dan dapat diulangi pada memori banding dan memori kasasi. 
(5) Hakim wajib membuka persidangan yang khusus untuk memeriksa pembuktian yang diajukan terdakwa sebagaimana dimaksud dalam ayat (4).

(6) Apabila terdakwa dibebaskan atau dinyatakan lepas dari segala tuntutan hukum dari perkara pokok, maka tuntutan perampasan harta benda sebagaimana dimaksud dalam ayat (1) dan ayat (2) harus ditolak oleh hakim.

\section{Pasal 38 C:}

Apabila setelah putusan pengadilan telah memperoleh kekuatan hukum tetap, diketahui masih terdapat harta benda milik terpidana yang diduga atau patut diduga juga berasal dari tindak pidana korupsi yang belum dikenakan perampasan untuk negara sebagaimana dimaksud dalam Pasal 38 B ayat (2), maka negara dapat melakukan gugatan perdata terhadap terpidana dan atau ahli warisnya."

Di antara Bab VI dan Bab VII ditambah bab baru yakni Bab VI A mengenai Ketentuan Peralihan yang berisi satu pasal, yakni Pasal 43 A yang diletakkan di antara Pasal 43 dan Pasal 44, sehingga keseluruhannya berbunyi sebagai berikut:

\section{BAB VI A}

\section{KETENTUAN PERALIHAN}

\section{Pasal 43 A}

(1) Tindak pidana korupsi yang terjadi sebelum Undang-undang Nomor 31 Tahun 1999 tentang Pemberantasan Tindak Pidana Korupsi diundangkan, diperiksa dan diputus berdasarkan ketentuan Undang-undang Nomor 3 Tahun 1971 tentang Pemberantasan Tindak Pidana Korupsi, dengan ketentuan maksimum pidana penjara yang menguntungkan bagi terdakwa diberlakukan ketentuan dalam Pasal 5, Pasal 6, Pasal 7, Pasal 8, Pasal 9, dan Pasal 10 Undang-undang ini dan Pasal 13 Undang-undang Nomor 31 Tahun 1999 tentang Pemberantasan Tindak Pidana Korupsi.

(2) Ketentuan minimum pidana penjara dalam Pasal 5, Pasal 6, Pasal 7, Pasal 8, Pasal 9, dan Pasal 10 Undang-undang ini dan

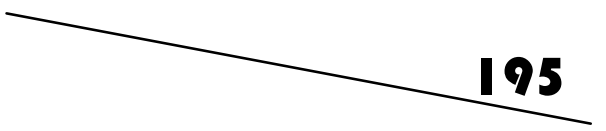


Pasal 13 Undang-undang Nomor 31 Tahun 1999 tentang Pemberantasan Tindak Pidana Korupsi tidak berlaku bagi tindak pidana korupsi yang terjadi sebelum berlakunya Undang-undang Nomor 31 Tahun 1999 tentang Pemberantasan Tindak Pidana Korupsi.

(3) Tindak pidana korupsi yang terjadi sebelum Undang-undang ini diundangkan, diperiksa dan diputus berdasarkan ketentuan Undang-undang Nomor 31 Tahun 1999 tentang Pemberantasan Tindak Pidana Korupsi, dengan ketentuan mengenai maksimum pidana penjara bagi tindak pidana korupsi yang nilainya kurang dari Rp 5.000.000,00 (lima juta rupiah) berlaku ketentuan sebagaimana dimaksud dalam Pasal 12 A ayat (2) Undang-undang ini.

Penambahan juga terdapat dalam BAB VII, sebelum Pasal 44 ditambah satu pasal baru yakni Pasal 43 B yang berbunyi sebagai berikut:

\section{Pasal 43B:}

Pada saat mulai berlakunya Undang-undang ini, Pasal 209, Pasal 210, Pasal 387, Pasal 388, Pasal 415, Pasal 416, Pasal 417, Pasal 418, Pasal 419, Pasal 420, Pasal 423, Pasal 425, dan Pasal 435 Kitab Undang-undang Hukum Pidana jis. Undang-undang Nomor 1 Tahun 1946 tentang Peraturan Hukum Pidana (Berita Republik Indonesia II Nomor 9), Undang-undang Nomor 73 Tahun 1958 tentang Menyatakan Berlakunya Undang-undang Nomor 1 Tahun 1946 tentang Peraturan Hukum Pidana untuk Seluruh Wilayah Republik Indonesia dan Mengubah Kitab Undang-undang Hukum Pidana (Lembaran Negara Tahun 1958 Nomor 127, Tambahan Lembaran Negara Nomor 1660) sebagaimana telah beberapa kali diubah terakhir dengan Undang-undang Nomor 27 Tahun 1999 tentang Perubahan Kitab Undang-undang Hukum Pidana Yang Berkaitan Dengan Kejahatan Terhadap Keamanan Negara, dinyatakan tidak berlaku.

Selain itu, terdapat dua Undang-undang lagi yang lahir pada era reformasi yang terkait dengan pemberantasan tindak pidana 
korupsi, yaitu Undang-Undang Nomor 30 Tahun 2002 tentang Komisi Pemberantasan Tindak Pidana Korupsi yang disahkan dan diundangkan pada tanggal 27 Desember 2002 dan tertulis dalam Lembaran Negara Republik Indonesia Tahun 2002 Nomor137, serta Undang-Undang Nomor 7 Tahun 2006 tentang Pengesahan United Nation Convention Against Corruption 2003 (Konvensi Perserikatan Bangsa-Bangsa Anti Korupsi 2003) yang disahkan dan diundangkan pada tanggal 18 April 2006 dan tertulis dalam Lembaran Negara Republik Indonesia Tahun 2006 Nomor $32 .{ }^{19}$

\section{Fikih dan Gagasan Anti Korupsi}

Dalam pembahasan fikih, di antara sekian banyak tindak pidana, hanya terdapat sembilan tindak pidana yang hukumannya secara tegas dinyatakan dalam al-Qur'an atau hadis. Yaitu, (1) perzinahan, (2) tuduhan perzinahan (qadhaf), (3) pencurian (sariqah), (4) mengganggu ketertiban umum dan membuat kerusakan (hirabah), (5) mengkonsumsi barang yang memabukkan (shurb al-khamr), (6) keluar dari Islam (riddah), (7) pemberontakan (baghy), (8) pembunuhan dan (9) penganiayaan. Tujuh tindak pidana pertama termasuk dalam katagori jarimah hudud, sedangkan dua tindak pidana terakhir adalah bagian dari jarimah qisas. Selain tindak pidana tersebut kadar hukumannya tidak diatur oleh nass al-Qur'an atau hadis dan diserahkan kepada penguasa untuk menentukan dan merumuskannya. Tindak pidana ini selanjutnya disebut dengan jarimah $t a^{\prime} z i r$.

Sekilas, amat mudah menentukan tindak pidana yang dikatagorikan sebagai jarimah ta'zir. Cukup melihat apakah tindak pidana tersebut termasuk ke dalam kelompok sembilan atau tidak. Tetapi sesungguhnya, penentuan jenis jarimah sebuah kejahatan jauh lebih sulit dari yang diperkirakan. Terutama ketika menyangkut kemiripan sebuah kejahatan dengan kejahatan

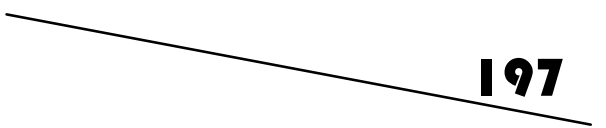


lainnya. Untuk itu kejelian memahami pengertian dan unsurunsur khusus setiap tindak pidana (jarimah) menjadi urgent.

Korupsi, sebagaimana telah dipaparkan secara detail sebelumnya, menurut Undang-undang antikorupsi adalah:

a. Setiap orang yang secara melawan hukum melakukan perbuatan memperkaya diri sendiri atau orang lain atau suatu korporasi yang dapat merugikan keuangan negara atau perekonomian negara.

b. Setiap orang yang secara melawan hukum melakukan perbuatan memperkaya diri sendiri atau orang lain atau suatu korporasi yang dapat merugikan keuangan negara atau perekonomian negara yang sementara dana itu diperuntukkan bagi penangulangan keadaan bahaya, bencana alam nasional, penanggulangan akibat kerusuhan sosial yang meluas, penanggulangan krisis ekonomi moneter dan penanggulangan tindak pidana korupsi.

c. Setiap orang yang dengan tujuan menguntungkan diri sendiri atau orang lain atau korporasi, menyalahgunakan kewenangan, kesempatan, atau sarana yang ada padanya karena jabatan atau kedudukan yang dapat merugikan keuangan negara atau perekonomean negara.

Ketiga definisi tersebut dapat memberikan pengertian bahwa korupsi adalah pengkhianatan terhadap kepercayaan yang diberikan, sehingga memposisikan pelakunya dalam fungsi ganda yang kontradiktif untuk keuntungan dirinya atau kelompoknya.

Pengertian korupsi sebagai pengkhianatan (الخيانة) atas kepercayaan ini sejalan dengan QS. Ali 'Imran (3): 161:

"Tidak mungkin seorang nabi berkhianat dalam urusan harta rampasan perang. barangsiapa yang berkhianat dalam urusan rampasan perang itu, Maka pada hari kiamat ia akan datang membawa apa yang dikhianatkannya itu, Kemudian tiap-tiap diri akan diberi pembalasan 
tentang apa yang ia kerjakan dengan (pembalasan) setimpal, sedang mereka tidak dianiaya." 20

Sabab al-nuzul ayat ini adalah adanya peristiwa raibnya sehelai kain wol hasil rampasan perang dalam catatan inventaris pasca perang. Sebagian sahabat menduga Rasulullah saw. telah melakukan korupsi dengan mengambil kain wol tersebut. Tetapi Allah menolak dugaan tersebut dan menjamin bahwa Rasulullah saw. tidak melakukan korupsi (pengkhianatan) seperti yang dituduhkan tersebut. ${ }^{21}$

Ayat tersebut secara tegas mengaitkan pengkhianatan (penyelewengan) terhadap kepercayaan (jabatan) dengan harta kekayaan. Jika dibandingkan dengan rumusan korupsi seperti yang ditegaskan Undang-undang anti korupsi, maka apa yang dikemukakan al-Qur'an tersebut dapat disebut sebagai tuduhan atas terjadinya praktek korupsi.

Di samping itu, di dalam al-Qur'an terdapat beberapa ayat yang secara eksplisit menunjukkan bahwa korupsi itu pengkhianatan atau penyelewengan terhadap kepercayaan, antara lain:

1. Dalam QS. al-Baqarah (2): 283, Allah mengemukakan kewajiban untuk menunaikan amanah sebagai lawan dari khiyanah (pengkhianatan):

Jika kamu dalam perjalanan (dan bermu'amalah tidak secara tunai) sedang kamu tidak memperoleh seorang penulis, Maka hendaklah ada barang tanggungan yang dipegang[180] (oleh yang berpiutang). akan tetapi jika sebagian kamu mempercayai sebagian yang lain, Maka hendaklah yang dipercayai itu menunaikan amanatnya (hutangnya) dan hendaklah ia bertakwa kepada Allah Tuhannya; dan janganlah kamu (para saksi) menyembunyikan persaksian. dan barangsiapa yang menyembunyikannya, Maka

${ }^{20}$ Departemen Agama RI, al-Qur'an dan Terjemahnya (Madinah: Mujamma' Khadim alH $\{$ aramain, |99|), h. 104.

${ }^{21}$ Al-Wahidy, Asbab Nuzul al-Qur'an (Beirut: Dar al-Fikr, 1989), h. 108.

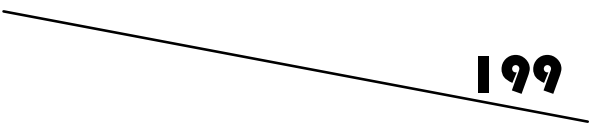


Sesungguhnya ia adalah orang yang berdosa hatinya; dan Allah Maha mengetahui apa yang kamu kerjakan. ${ }^{22}$

Perintah melaksanakan amanah (kepercayaan) atas harta yang dititipkan seperti tersebut dalam ayat di atas mempunyai pemahaman sebaliknya (mafhum muhkalafah) bahwa Allah melarang korupsi (pengkhianatan) terhadap harta yang dititipkan tersebut.

2. Dalam QS. al-Anfal (8): 27, secara tegas Allah melarang untuk melakukan praktek korupsi (pengkhianatan) terhadap amanah (kepercayaan) yang diberikan;

Hai orang-orang yang beriman, janganlah kamu mengkhianati Allah dan Rasul (Muhammad) dan (juga) janganlah kamu mengkhianati amanat-amanat yang dipercayakan kepadamu, sedang kamu Mengetahui.23

3. Dalam QS. al-Nisa' (4): 58, Allah memerintahkan untuk menunaikan amanah (kepercayaan) kepada penerimanya:

Sesungguhnya Allah menyuruh kamu menyampaikan amanat kepada yang berhak menerimanya, dan (menyuruh kamu) apabila menetapkan hukum di antara manusia supaya kamu menetapkan dengan adil. Sesungguhnya Allah memberi pengajaran yang sebaikbaiknya kepadamu. Sesungguhnya Allah adalah Maha mendengar lagi Maha Melihat.

Mustafa al-Maraghy dalam menafsirkan ayat ini menyatakan bahwa penunaian amanah dalam ayat tersebut terbagi dalam tiga bentuk: (1) penunaian amanah yang diperoleh dari Allah (amanah al-'abd ma' rabbih), (2) penunaian amanah yang diperoleh dari sesama (amanah al-'abd $m a^{\prime}$ alnas), dan (3) penunaian amanah yang diperoleh dari dirinya sendiri (amanah al-'abd ma' nafsih). ${ }^{24}$ Siapapun yang

\footnotetext{
${ }^{22}$ lbid., h. 71 .

${ }^{23}$ /bid., h. 264.

${ }^{24}$ Mustafa al-Maraghy, Tafsir al-Maraghy (Beirut: Dar al-Fikr, 1989), h. 233.
} 
mengabaikan amanah-amanah tersebut, berarti ia telah melakukan korupsi (pengkhianatan).

Dalam hadis Rasulullah disebutkan tentang praktek suap menyuap yang berakibat timbulnya pengkhianatan terhadap wewenang yang diberikan. Rasulullah melaknat praktek tersebut sebagaimana ditegaskan dalam hadis riwayat $\mathrm{Abu}$ Dawud berikut ini:

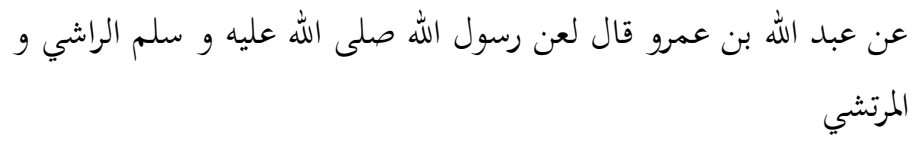

Diriwayatkan dari 'Abd Allah ibn 'Umar berkata, "Rasulullah melaknat orang yang memberi suap dan penerima suap."

Dalam pembahasan fikih jinayah, pengambilan harta orang lain yang dianggap sebagai jarimah hudud hanya ada dua: pencurian (sariqah) dan perampokan (hirabah). Karena itu, untuk menentukan apakah korupsi sebagai pengkhianatan termasuk dalam kelompok hudud atau $t a^{\prime} z i r$, harus dilakukan pemahaman dan pengkajian yang detail apakah korupsi dapat digolongkan sebagai pencurian (sariqah) atau perampokan (hirabah).

Pencurian didefinisikan sebagai "mengambil harta orang lain secara diam-diam dari tempat penyimpanannya yang layak". ${ }^{25}$ Dari pengertian tersebut para ahli fikih merumuskan bahwa unsur-unsur khusus delik sariqah (pencurian) adalah: ${ }^{26}$

a. Mengambil harta secara diam-diam (tanpa sepengetahuan dan kerelaannya).

b. Barang yang dicuri berupa harta yang bergerak, berharga, memiliki tempat penyimpanan yang layak dan sampai nisab.

c. Harta yang dicuri milik orang lain, dan

d. Terdapat iktikad tidak baik.

${ }^{25}$ Zakariya al-Ansary, Fath al-Wahhab bi Sharh Manhaj al-Tullab, Vol. 2 (Bandung: Shirkah alMa'arif, tt.), h. 159.

26 'Abd al-Qadir 'Audah, al-Tashri' al-Jinaiy al-Islamy, Vol. 2 (Beirut: Mussasah al-Risalah, 1992), h. 5|4-608.

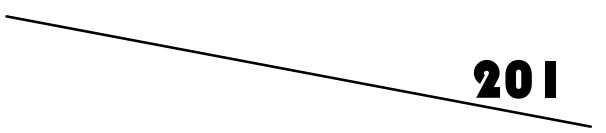


Sedangkan perampokan oleh para ahli fikih didefinisikan "keluar untuk mengambil harta orang lain dengan terang-terangan dan menggunakan cara kekerasan". ${ }^{27}$

Melihat definisi dan unsur-unsur tersebut dapat ditegaskan bahwa korupsi dalam pengertian pengkhianatan sebagaimana dijabarkan oleh Undang-undang antikorupsi tidak termasuk jarimah sariqah (pencurian) maupun jarimah hirabah (perampokan) dengan dua alasan:

1. Korupsi tidak memenuhi unsur-unsur yang terdapat pada pencurian dan perampokan. Dalam pencurian, ketentuan harta yang dicuri harus diambil dari tempat penyimpanan (al-hirz) yang memang disediakan dan biasa digunakan oleh pemiliknya. Sedangkan dalam tindak pidana korupsi harta atau kewenangan (kekuasaan terhadap harta) secara resmi dipercayakan kepada pelaku korupsi, bukan di tempatkan secara langsung oleh pemiliknya di tempat penyimpanan. Dalam perampokan, harta diambil dengan cara kekerasan, sedangkan dalam korupsi tidak terdapat unsur kekerasan.

2. Korupsi sebagai pengkhianatan terhadap kepercayaan ditegaskan oleh Rasulullah sebagai tindak pidana yang tidak dikenai hukuman potong tangan yang berarti tidak termasuk dalam tindak pidana pencurian. Rasulullah bersabda:

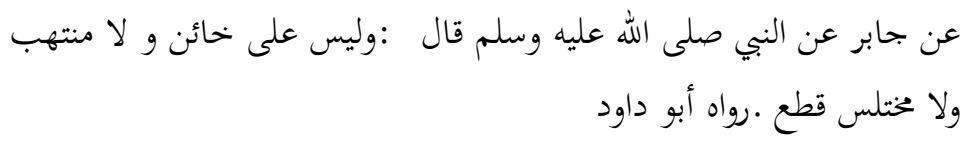

Diriwayatkan dari Jabir dari Nabi saw., beliau bersabda, "Tidak ada potong tangan untuk orang yang berkhianat, orang yang menjambret dan orang yang mencopet."

Korupsi dengan demikian tidak termasuk ke dalam jarimah hudud dan termasuk dalam katagori jarimah ta'zir. Sebab bagaimanapun korupsi adalah perbuatan maksiat yang tidak

27 Ibid., h. 638. 
termasuk ke dalam wilayah hudud dan qisas, sehingga dipastikan tindak pidana korupsi termasuk bagian dari jarimah ta'zir. Memang, dalam membatasi ruang lingkup ta'zir ini, para ulama berbeda pendapat. Menurut sebagian ulama, seperti Ahmad Fathy Bahanshy, $t a^{\prime} z i r$ terbagi kepada tiga macam, yaitu:

1. Ta'zir terhadap perbuatan maksiat (al-ma'ashy), seperti melakukan ghasab terhadap harta orang lain, berciuman dengan lawan jenis yang bukan istrinya dan lain-lain.

2. Ta'zir karena adanya kemaslahatan umum (al-maslahah al'ammah). Ini sebagaimana dicontohkan oleh Rasulullah yang menahan seseorang yang diduga mencuri unta. Ketika dugaan tersebut tidak terbukti, maka Rasulullah melepasnya. Penahanan tersebut dilandaskan kepada maslahah, yaitu agar orang tersebut tidak melarikan diri atau menghilangkan barang bukti.

3. Ta'zir terhadap pelanggaran-pelanggaran selain maksiat (almukhalafat). Misalnya sering meninggalkan perbuatanperbuatan yang disunnahkan atau sering melakukan hal-hal yang dimakruhkan..$^{28}$

'Abd al-Rahman al-Maliky dalam bukunya, Nizam al-'Uqubat, mengurai jenis-jenis $t a^{\prime} z i r$ sebagai berikut: ${ }^{29}$

1. Pelanggaran terhadap kehormatan diri.

2. Pelanggaran terhadap nama baik.

3. Pelanggaran terhadap akal.

4. Pelanggaran terhadap harta benda.

5. Pelanggaran terhadap keamanan dan ketertiban.

6. Kejahatan yang mengganggu keselamatan negara.

7. Pelanggaran terhadap ajaran agama.

Walaupun korupsi digolongkan sebagai jarimah ta'zir, tidak berarti derajat kejahatannya lebih rendah dari kejahatan lainnya.

${ }^{28}$ Ahmad Fathy Bahansy, al-'Uqubah fi al-Figh al-Islamy (Kairo: Dar al-Shuruq, 1989), h. 130.

29 'Abd al-Rahman al-Maliky, Nizam al-'Uqubat (Beirut: Dar al-Ummah, 1990), h. 180.

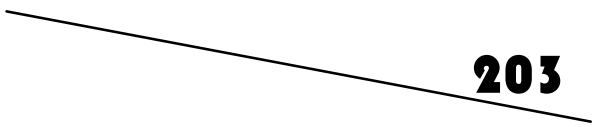


Bahkan, menurut kesimpulan mujtahid, ada jarimah ta'zir yang sepadan dengan kejahatan hudud atau qisas. Hal ini dapat dilihat dari adanya kemungkinan pelaksanaan hukuman ta'zir dalam bentuk hukuman mati yang sepadan dengan sebagian hukuman untuk jarimah hudud dan qisas $^{30}$.

\section{Penutup}

Kejahatan yang bernama korupsi tidak pernah ditolerir oleh Islam. Di dalam al-Qur'an dan hadis terdapat terminologi alkhiyanah (pengkhianatan terhadap kepercayaan yang diberikan) yang mencakup tindak pidana korupsi yang termasuk dalam domain jarimah ta'zir, yaitu jarimah (delik pidana) yang ketentuan dan bentuk hukumannya tidak ditentukan oleh al-Qur'an maupun hadis Nabi, tetapi didasarkan kepada maslahah yang dirumuskan oleh hakim atau ulu al-amr (pemerintah). Dengan demikian, korupsi itu terlarang karena ada banyak ayat al-Qur'an dan hadis Nabi yang melarangnya. Tetapi hukuman terhadap pelaku korupsi tidak ditentukan oleh nass, sehingga bersifat elastis sesuai kemaslahatan yang dirumuskan. Tugas utama kita saat ini adalah merumuskan secara komprehensif sebuah karya fikih yang dapat menjadi acuan untuk melawan tindak pidana korupsi.

\section{Daftar Rujukan}

'Abd al-Qadir 'Audah, al-Tashri' al-Jinaiy al-Islamy, Vol. 2, Beirut, Mussasah al-Risalah, 1992.

'Abd al-Rahman al-Maliky, Nizam al-Uqubat, Beirut, Dar alUmmah, 1990.

Ahmad Fathy Bahansy, al-'Uqubah fi al-Fiqh al-Islamy, Kairo, Dar alShuruq, 1989.

Alatas, The Sociology of Corruption, Singapore, Times International, 1980.

${ }^{30}$ Lihat Wahbah al-Zuhaily, al-Fiqh al-Islamy wa Adillatuh, Vol. 7 (Damaskus: Dar al-Fikr, 2004), h. 5594. 
Al-Wahidy, Asbab Nuzul al-Qur'an, Beirut, Dar al-Fikr, 1989.

Andi Hamzah, Korupsi di Indonesia: Masalah dan Pemecahannya, Jakarta, Gramedia Pustaka Umum, 1991.

Baharuddin Lopa, Permasalahan dan Penegakan Hukum di Indonesia, Jakarta, Bulan Bintang, 1987.

Evi Hartanti, Tindak Pidana Korupsi, Jakarta, Sinar Grafika Offset, 2005.

Hermien Hadiati Koeswadji, Korupsi di Indonesia: Dari Delik Jabatan ke Tindak Pidana Korupsi, Bandung, PT. Citra Aditya Bakti, 1994.

J. W. Schoorl, Modernisasi: Pengantar Sosiologi Pembangunan Negara Sedang Berkembang, Jakarta, Gramedia, 1980.

Mustafa al-Maraghy, Tafsir al-Maraghy, Beirut, Dar al-Fikr, 1989.

Nilawati, "Penyakit yang Menggiurkan Itu Bernama Korupsi", dalam Suyitno, et.al., Korupsi: Hukum \& Moralitas Agama, Yogyakarta, Gama Media, 2006.

Reader's Digest, Word Power Dictionary, Sydney, The Reader's Digest Association Limited, 2001.

Robert Klitgard, Controlling Corruption, terjemah: Hermoyo (Jakarta: Yayasan Obor Indonesia, 1998.

Syeid Husein Alatas, Sosiologi Korupsi, Jakarta, LP3ES, 1982.

'Umar Sulaiman al-Ashqar, Tarikh al-Figh al-Islamy, Kuwait, Maktabah al-Falah, 1982.

W. A. Bonger, Pengantar Tentang Kriminologi, Jakarta, Ghalia Indonesia, 1982.

Wahbah al-Zuhaily, al-Figh al-Islamy wa Adillatuh, Vol. 7, Damaskus, Dar al-Fikr, 2004.

Zakariya al-Ansary, Fath al-Wahhab bi Sharh Manhaj al-Tullab, Vol. 2, Bandung, Shirkah al-Ma'arif, tt.

Departemen Agama RI, al-Qur'an dan Terjemahnya, Madinah, Mujamma' Khadim al-H\{aramain, 1991.

Departemen Pendidikan dan Kebudayaan, Kamus Besar Bahasa Indonesia, Jakarta, PN. Balai Pustaka, 1976.

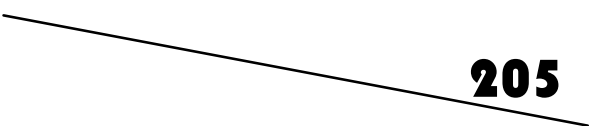


Anonim, "Modules", dalam http://www.kpk.go.id, dikases pada 20 Pebruari 2010. 